\title{
Distribution trend of trace elements in digestate exposed to air: laboratory-scale investigations using DGT-based fractionation
}

\section{Authors and affiliation}

Andreina Laera ${ }^{\mathrm{a}, \mathrm{b}}$, Rémy Buzier ${ }^{\mathrm{b}}$, Gilles Guibaud ${ }^{\mathrm{b}}$, Giovanni Esposito ${ }^{\mathrm{c}}$, Eric D. van Hullebusch $^{\mathrm{d}}$

${ }^{a}$ University of Paris-Est, Laboratoire Géomatériaux et Environnement (EA 4508), UPEM, 77454 Marne-la-Vallée, France, andreina.laera@u-pem.fr or piedelibero89@gmail.com

${ }^{\mathrm{b}}$ University of Limoges, PEIRENE, Equipe Développement d'indicateurs ou prévision de la qualité des eaux, URA IRSTEA, 123 Avenue Albert Thomas, 87060 Limoges Cedex, France ${ }^{\mathrm{c}}$ University of Napoli “Federico II”, Department of Civil, Architectural and Environmental Engineering, via Claudio 21, 80125 Napoli, Italy

${ }^{\mathrm{d}}$ Institut de Physique du Globe de Paris, Sorbonne Paris Cité, Université Paris Diderot, UMR 7154, CNRS, F-75005 Paris, France

*Corresponding author: remy.buzier@unilim.fr 


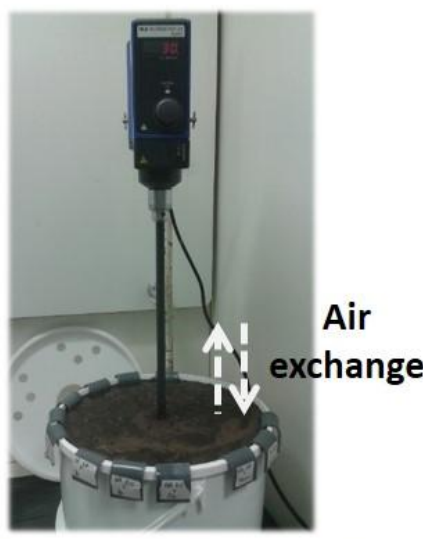

Lab-scale digestate tank
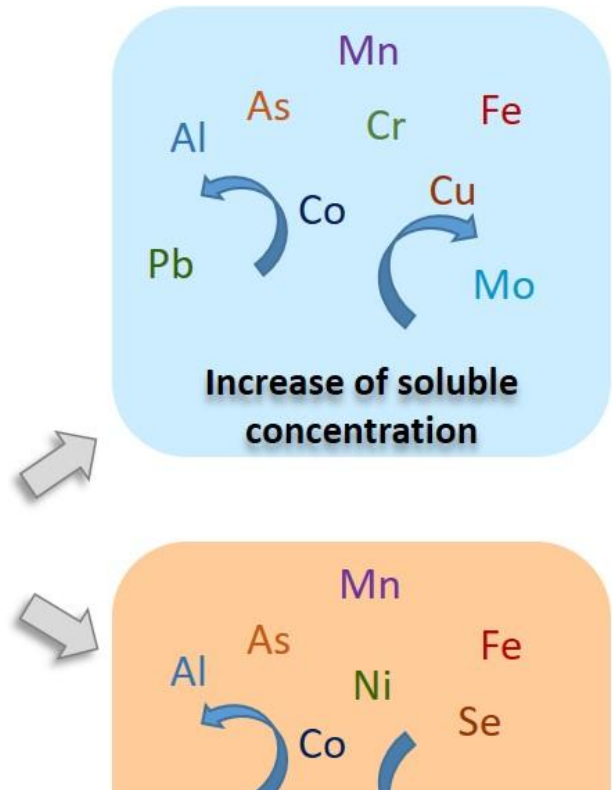

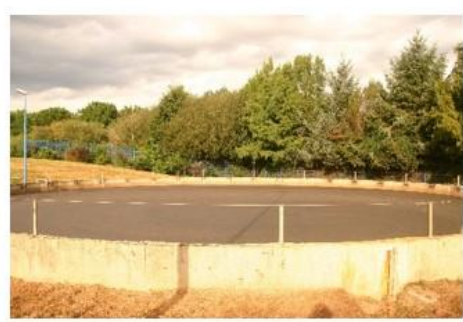

Mobility during digestate management?

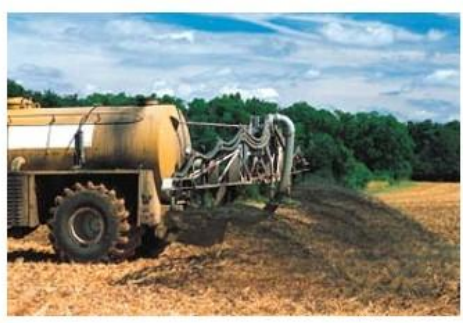

Variation of DGT-labile concentration 


\section{Highlights}

- Distribution trend of 14 trace elements was studied in digestate under air exposure;

- DGT was used as trace elements fractionation tool to assess the labile fraction;

- Aeration promoted dissolution of $\mathrm{Al}, \mathrm{As}, \mathrm{Co}, \mathrm{Cr}, \mathrm{Cu}, \mathrm{Fe}, \mathrm{Mn}, \mathrm{Mo}$ and $\mathrm{Pb}$;

- Forced aeration promoted an increase of labile Al, As, Co, Mo, Ni, Sb, Se and W;

- $\mathrm{Al}, \mathrm{As}, \mathrm{Co}, \mathrm{Cr}, \mathrm{Cu}, \mathrm{Fe}, \mathrm{Mn}$ and $\mathrm{Pb}$ were mainly present as particulate despite aeration. 


\section{Distribution trend of trace elements in digestate exposed to air: laboratory-scale investigations using DGT-based fractionation}

\section{Authors and affiliation}

Andreina Laera $^{\mathrm{a}, \mathrm{b}}$, Rémy Buzier ${ }^{\mathrm{b} *}$, Gilles Guibaud ${ }^{\mathrm{b}}$, Giovanni Esposito ${ }^{\mathrm{c}}$, Eric D. van Hullebusch ${ }^{\mathrm{d}}$

${ }^{a}$ University of Paris-Est, Laboratoire Géomatériaux et Environnement (EA 4508), UPEM, 77454

Marne-la-Vallée, France, andreina.laera@u-pem.fr or piedelibero89@gmail.com

${ }^{\mathrm{b}}$ University of Limoges, PEIRENE, Equipe Développement d'indicateurs ou prévision de la qualité des eaux, URA IRSTEA, 123 Avenue Albert Thomas, 87060 Limoges Cedex, France

${ }^{\mathrm{c}}$ University of Napoli "Federico II", Department of Civil, Architectural and Environmental Engineering, via Claudio 21, 80125 Napoli, Italy

${ }^{\mathrm{d}}$ Institut de Physique du Globe de Paris, Sorbonne Paris Cité, Université Paris Diderot, UMR 7154, CNRS, F-75005 Paris, France

*Corresponding author: remy.buzier@unilim.fr

1 The use of digestate as amendment for agricultural soils has already been proposed as an

2 alternative to mineral fertilizers or undigested organic matter. However, little information is

3 available concerning the effect of digestate atmospheric exposure on trace elements speciation

4 and, consequently, on their mobility and bio-accessibility when digestate is stored in open tanks 
5 or handled before land spreading. In this study, we investigated at laboratory-scale the effect of 6 digestate aeration on the distribution of $\mathrm{Al}, \mathrm{As}, \mathrm{Cd}, \mathrm{Co}, \mathrm{Cr}, \mathrm{Cu}, \mathrm{Fe}, \mathrm{Mn}, \mathrm{Mo}, \mathrm{Ni}, \mathrm{Pb}, \mathrm{Sb}, \mathrm{Se}$ and

7 W using the diffusive gradients in thin films technique (DGT)-based fractionation. For this

8 purpose, experiments were performed to assess the variation in distribution between the labile, 9 soluble and particulate fractions over time in digested sewage sludge during passive and forced 10 aeration. Results showed that aeration promoted a dissolution of $\mathrm{Al}, \mathrm{As}, \mathrm{Co}, \mathrm{Cr}, \mathrm{Cu}, \mathrm{Fe}, \mathrm{Mn}, \mathrm{Mo}$ 11 and $\mathrm{Pb}$, suggesting a possible increase in their mobility that may likely occur during storage in 12 open tanks or handling before land spreading. Labile elements' fraction increased only during 13 forced aeration (except for Fe and Mn), suggesting that their short-term bio-accessibility can 14 increase only after significant aeration as the one assumed to occur when land spreading takes 15 place.

\section{Keywords}

Metals

Metalloids

Digested sewage sludge

Fractionation

Diffusive Gradients in Thin Films (DGT)

Speciation 


\section{Introduction}

16 The use of digestate, a by-product of anaerobic digestion of organic residues (Möller and Müller,

17 2012), as amendment for agricultural soils and substitute of mineral fertilizers (Riva et al., 2016)

18 is gaining importance as a result of the increasing use of biogas plants running on different

19 organic feedstock (Scarlat et al., 2018). However, the presence of potentially hazardous trace

20 elements (TEs) (e.g. cadmium $(\mathrm{Cd})$, copper $(\mathrm{Cu})$ and lead $(\mathrm{Pb}))$ in digestate, may prevent its use

21 in agriculture (Kupper et al., 2014; Tampio et al., 2016). The bio-accessibility of TEs not only

22 depends on their total concentration but also on their speciation (Hooda, 2010). Therefore,

23 screening of TEs speciation is required to assess the harm or benefit associated with digestate

24 before land spreading (van Hullebusch et al., 2016).

25 According to the spreading season, digestate could be stored for several months (Plana and

26 Noche, 2016) in open tanks (Boulamanti et al., 2013; Liebetrau et al., 2010). During storage in

27 open tanks and handling before land spreading, digestate will be exposed to air. Such exposure

28 will alter the anaerobic status of digestate which in turn may alter the speciation of TEs and

29 consequently affect their mobility and bio-accessibility in the environment. Although no

30 information is available, to the best of our knowledge, for digestate, Øygard et al. (2007)

31 demonstrated that atmospheric exposure impacts on TEs' distribution in municipal solid waste

32 landfill leachates. Therefore, new investigations are needed to assess the potential impact of

33 digestate aeration on TEs speciation for risk assessment before land application.

34 Total element content in digestate is commonly determined after solubilization (usually acid

35 digestion) with conventional methods for TEs analysis in liquids such as ICP-MS (Dragicevic et

36 al., 2018a) and ICP-OES (Cao et al. 2018). The mobility and bio-accessibility of TEs in digestate

37 are usually studied using different techniques such as sequential extractions like the modified 
38 Tessier method (Ortner et al., 2014) or extraction with deionized water only (Dragicevic et al.,

39 2018b). Alternatively, the diffusive gradients in thin films technique (DGT) can be used to screen

40 the presence of labile elements (i.e. the most readily bio-accessible form of TEs (Zhang and

41 Davison, 2015) into the environmental matrix. In particular, DGT-based fractionation was

42 recently validated for digestate matrix (Laera et al., 2019). Compared to conventional

43 fractionation techniques, DGT has the advantage of measuring the targeted elements in situ

44 without affecting the sample and speciation of TEs (Vrana et al., 2005). Moreover, DGT

45 technique increases the sensitivity of TEs monitoring compared to total acid-soluble

46 measurements (Laera et al., 2019).

47 Here, the effects of aeration of digested sewage sludge on mobility and bio-accessibility of

48 fourteen TEs were investigated to assess their fate before land spreading. The TEs investigated in

49 this study are either under EU regulation for application of sewage sludge in agriculture

50 (European Commission, 2016) (i.e. $\mathrm{Cd}, \mathrm{Cr}, \mathrm{Cu}, \mathrm{Ni}$ and $\mathrm{Pb}$ ), or selected based on previous studies

51 (Dragicevic et al., 2018b; Hamnér and Kirchmann, 2015; Laera et al., 2019; Øygard et al., 2007)

52 (i.e. $\mathrm{Al}, \mathrm{As}, \mathrm{Co}, \mathrm{Fe}, \mathrm{Mn}, \mathrm{Mo}$ and $\mathrm{Se}$ ). Antimony ( $\mathrm{Sb}$ ) and $\mathrm{W}$ were included because they could be

53 present in sewage sludge (Fu and Tabatabai, 1988; Healy et al., 2016; McBride, 2003) and

54 generate environmental issues due to their accumulation in plants (Arai, 2010; Charter et al., 55 1995).

56 In this study, the conventional particulate/soluble fractionation indicating potential TEs' mobility 57 was implemented with a DGT-based fractionation procedure to monitor the most bio-accessible 58 species. Experiments were performed at laboratory-scale to assess the time variation of labile, 59 soluble and particulate TEs during passive and forced aeration of digestate. Results were 
60 discussed assuming that the experimental work can mimic digestate oxidation during storage in 61 open tanks or handling before land spreading. 


\section{2. Material and methods}

\section{2.1. Digestate sample}

64 Digested sewage sludge was collected from a municipal wastewater treatment plant located in 65 Limoges (France). The digestate derived from activated sludge treated by a mesophilic anaerobic 66 digestion process. About $18 \mathrm{~L}$ of sample was collected directly from a pipe before discharge in an 67 open storage tank. The sample was collected in a polypropylene (PP) bucket up to maximum 68 capacity and closed with a lid to limit sample exposure to open air. Once in the laboratory, the 69 sample was stored at $4^{\circ} \mathrm{C}$ for less than 24 hours before starting the experiment.

\section{2.2. DGT preparation}

71 We used Chelex-DGTs for cationic species (Al, Cd, Co, Cr (III), Cu, Fe, Mn, Ni and Pb) and 72 zirconia-DGTs (Zr-DGTs) for anionic species (As, Mo, Sb, Se and W). Each DGT consisted of a 73 binding gel (Chelex or $\mathrm{Zr}$ ), a diffusive gel and a filter membrane enclosed in a piston type holder 74 (purchased from DGT Research, Lancaster, UK). Chelex binding gels were prepared according to 75 the procedure described by Zhang et al. (1998), whereas Zr binding gels were made according to 76 Devillers et al. (2016). Diffusive gels were standard polyacrylamide gels (15\% acrylamide and $770.3 \%$ agarose-derived cross linker, $0.77 \mathrm{~mm}$ thick) prepared according to Zhang et al. (1998) and 78 filter membranes were made of cellulose acetate $(0.2 \mu \mathrm{m}$ pore size, $0.12 \mathrm{~mm}$ thickness, 79 Whatman, UK).

80 2.3. Experimental set-up

81 About $18 \mathrm{~L}$ of digested sludge were poured into a laboratory-scale PP tank placed under a fume 82 hood and continuously stirred with an overhead plastic propeller at $30 \mathrm{rpm}$ (Figure S1) in order to 83 control experimental conditions. Stirring allows optimizing air transfer within the digestate and 
84 therefore represents a "worst case scenario" compared to unstirred real scale tanks. A Tinytag 85 data logger (TG-4100, Gemini Data Loggers, UK) was used to record the temperature in the 86 sample every $10 \mathrm{~min}$. The surface of the sample was exposed to air to promote oxidation of the 87 sample during 10 weeks. The surface to volume ratio varied from $0.39 \mathrm{dm}^{-1}\left(7.1 \mathrm{dm}^{2}: 18 \mathrm{~L}\right)$ to $880.51 \mathrm{dm}^{-1}\left(7.1 \mathrm{dm}^{2}: 14 \mathrm{~L}\right)$ during the experiment because of multiple sample collection (see 89 below). Therefore, passive aeration was progressively favored while the experiment continued. 90 Then, aeration was enhanced during 2 supplementary weeks by introducing 4 micro-bubble air 91 diffusers in the digested sludge. All diffusers were connected to air pumps (Newair or Optima) 92 having airflow rates from 60 to $200 \mathrm{~L} / \mathrm{h}$.

93 Labile TEs were sampled by deploying three DGTs probes composed either of Chelex or $\mathrm{Zr}$ for $9424 \mathrm{~h}$ in the digested sludge. We choose a $24 \mathrm{~h}$ deployment because it was shown previously to be a 95 good compromise for the studied elements in digestate (Laera et al., 2019).

96 DGTs were deployed according to the following sequence (Figure S1): every day for the 6 first 97 consecutive days; once per week from week 2 to 10 ; twice per week for weeks 11 and 12. Blanks 98 DGT devices were also prepared in duplicate and treated alongside exposed devices every week.

99 After DGTs' retrieval, we measured dissolved $\mathrm{O}_{2}$, redox potential $\left(\mathrm{E}_{\mathrm{h}}\right)$ and $\mathrm{pH}$. Additionally, we 100 collected an aliquot of sample to measure total and volatile solids (TS and VS), total and volatile 101 suspended solids (TSS and VSS) and soluble TEs. Additionally, we monitored sulfate ( $\left.\mathrm{SO}_{4}{ }^{2-}\right)$ 102 concentration.

103 2.4. Analytical procedures

104 2.4.1. Physicochemical analysis

$105 \mathrm{pH}$ and $\mathrm{E}_{\mathrm{h}}$ were measured with a Mettler Toledo $\mathrm{pH}$ meter and a Radiometer electrode, 106 respectively. Dissolved oxygen was measured using a ProODO ${ }^{\mathrm{TM}}$ optical sensor (YSI). Each 
sampling time, about $90 \mathrm{~mL}$ of sample was collected in duplicate to measure the total solids (TS), volatile solids (VS), total suspended solids (TSS) and volatile suspended solids (VSS) according to the French standard AFNOR NF T90-105 method.

110 The supernatant recovered during the TSS and VSS analysis was conserved to determine soluble 111 TEs (see section 2.4.2.).

112 2.4.2. Sample treatment and trace elements analysis

113 Total elements' content was determined at the beginning and at the end of the experiment using 5 $114 \mathrm{~g}$ of raw sample. Each sampling time, soluble elements' concentration was determined from the 115 supernatant recovered during TSS determination. Supernatants and raw samples in duplicate were 116 acid digested with $6 \mathrm{~mL}$ of $69 \% \mathrm{HNO}_{3}$ and $3 \mathrm{~mL}$ of $37 \% \mathrm{HCl}$ in a microwave oven (Multiwave $117 \mathrm{GO}$, Anton Paar $\mathrm{GmbH}$ ) at $180^{\circ} \mathrm{C}$ for $60 \mathrm{~min}$.

118 TEs were analyzed by inductively coupled plasma mass spectrometry (ICP-MS, Agilent 7700×) 119 except for Fe which was analyzed by microwave plasma atomic emission spectroscopy (MP120 AES, Agilent 4210). Blanks and quality controls at 5 and $10 \mu \mathrm{g} / \mathrm{L}$ were analyzed every 10 121 samples. The recovery was equal or above $86 \%$ for each element, except for $\mathrm{Sb}$ and $\mathrm{W}$ which was 122 equal or above $79 \%$ and $76 \%$, respectively, among all analyses.

\section{2.5. Element's fractionations calculation}

124 The fractionation procedure is presented in Figure 1. Particulate elements' concentration was 125 calculated by subtracting the soluble to the initial total elements content. 


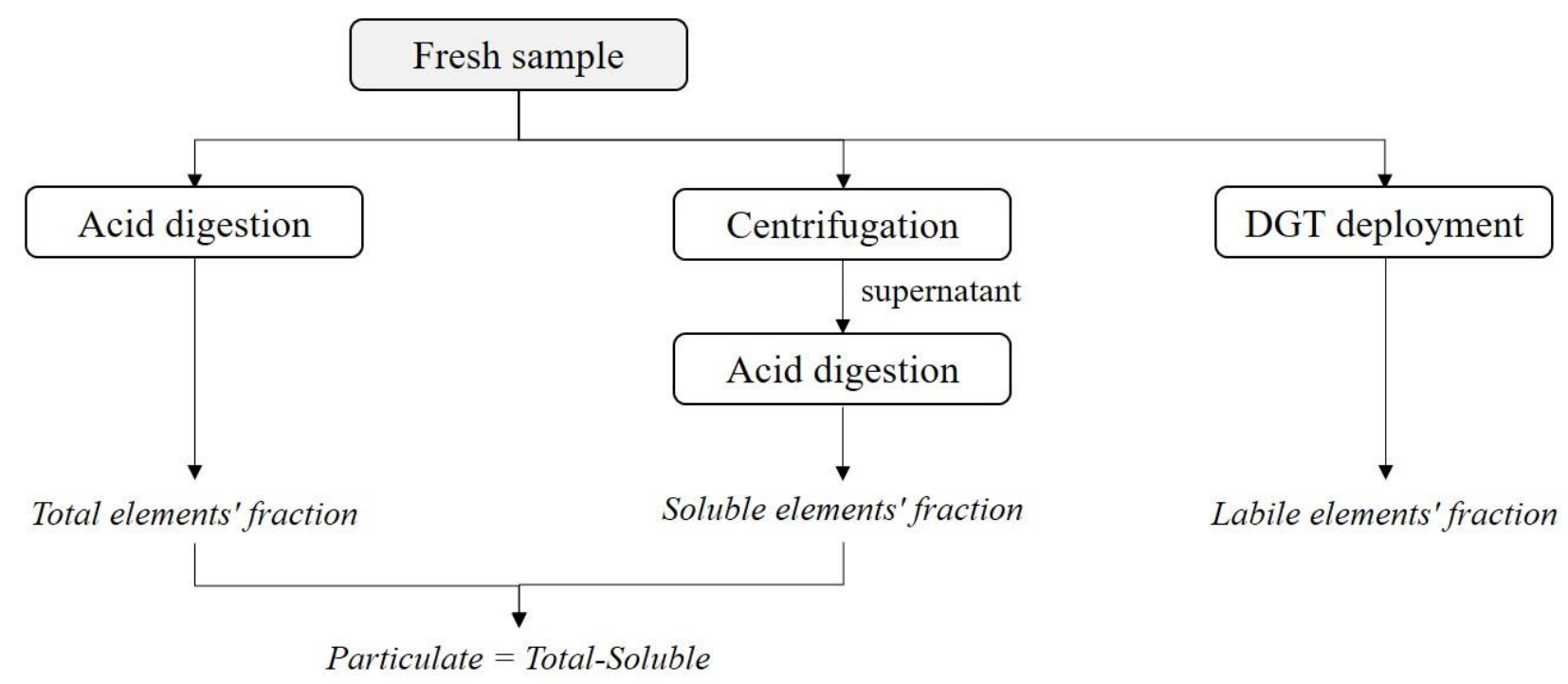

127 Figure 1. Fractionation procedure adopted in this study to estimate total, soluble, particulate and labile elements' fractions.

128 After retrieval from the digested sludge, DGT samplers were rinsed with ultrapure water and 129 disassembled to recover the binding gels and determine labile elements concentration. The 130 accumulated mass (m) was determined following elution of binding gels in $2 \mathrm{~mL}$ of $1 \mathrm{M} \mathrm{HNO}_{3}$ 131 or $5 \times 10^{-3} \mathrm{M} \mathrm{NaOH}$ and $0.5 \mathrm{M} \mathrm{H}_{2} \mathrm{O}_{2}$ for 24 hours for Chelex and Zr-binding gels, respectively 132 (see Table $\mathrm{S} 1$ for elution yields). The concentration of labile TEs, $\mathrm{C}_{\mathrm{DGT}}$, was then derived using 133 equation (1) based on Fick's first law (Zhang and Davison, 1995):

$134 \quad C_{D G T}=\frac{m \times \Delta_{M D L}}{\mathrm{D} \times \mathrm{t} \times \mathrm{A}} \quad, \quad$ Eq. (1)

135 where $\Delta_{\mathrm{MDL}}$ is the thickness of the material diffusion layer (i.e. diffusive gel plus membrane, 0.89 $136 \mathrm{~mm}), \mathrm{t}$ is the time of DGT samplers' exposure in the sludge (24h), D is the coefficient of 137 diffusion of the considered element and A is the geometric area of the DGT holder window (3.14 $138 \mathrm{~cm}^{2}$ ). D values were taken from literature (Table S2) and corrected for the average temperature 139 recorded during each deployment using Stokes-Einstein relation (Zhang and Davison, 1999). 
4 The method's limits of detection and quantification (namely MLD and MLQ for total and soluble 141 elements or MLD ${ }_{\text {DGT }}$ and MLQDGT for labile elements) are displayed in Table S3 and S4. 


\section{Results and discussion}

\section{3.1. Sample characterization}

144 The characteristic of the digested sewage sludge (TS, VS and water concentration) are presented

145 in Figure S2. The results show that the water concentration and the VS content is nearly constant 146 throughout the experiment. In particular, the average water content was $96.2 \% \pm 1.6$ and the 147 average VS content was $63.9 \% \pm 1.3$. Moreover, the average $\mathrm{pH}$ of the digested sludge was $7.8 \pm$ 1480.3 and the $E_{h}$ was below $-50 \mathrm{mV}$, whatever the aeration of the sludge. The latter is shown in 149 Figure S3.

150 The total elements concentration in the digested sludge is shown in Table S5. Except for Cd, Mo 151 and $\mathrm{Ni}$, the concentration of total elements is not significantly different $(\mathrm{p}>0.05)$ at the beginning 152 and at the end of the experiment. For total $\mathrm{Cd}$, Mo and Ni content the difference was significant 153 and could derive from an artifact caused by multiple sampling during the experiment if these 154 elements were not homogenously distributed in the sludge.

\section{3.2. Particulate and soluble concentrations of elements}

156 Soluble concentrations of $\mathrm{Cd}, \mathrm{Ni}, \mathrm{Sb}, \mathrm{Se}$ and $\mathrm{W}$ were below the method's limits of detection or 157 quantification (i.e. lower than 12, 721, 102, 1077 and $69 \mu \mathrm{g} / \mathrm{L}$, respectively) during the whole 158 experiment and the impact of aeration on their distribution cannot be discussed. For the other 159 elements (Figure S4), three different trends were observed. An example of each trend is given in 160 Figure 2. Fe and Mn showed limited variations of their particulate and soluble concentrations 161 during the first 15 days of passive aeration. Then, their soluble concentrations doubled up to the $16266^{\text {th }}$ day of aeration with a limited influence on their particulate concentration. From the $76^{\text {th }}$ day 163 of passive aeration and during the two weeks of forced aeration, the soluble concentration of Fe 
and $\mathrm{Mn}$ rapidly doubled. This rapid release in solution generated a slight decrease in particulate

$165 \mathrm{Fe}$ (i.e. 4\% less) and $\mathrm{Mn}$ (i.e. 5\% less). Soluble concentrations of $\mathrm{Al}, \mathrm{Co}, \mathrm{Cr}, \mathrm{Cu}, \mathrm{Mo}$ and $\mathrm{Pb}$ were

166 below MLD or MLQ during most of the passive aeration sequence (Figure 2, Figure S4).

167 However, during forced aeration, the soluble concentration of these elements increased above the 168 detection limits and was followed by a decrease of their particulate concentration. In particular, 169 the soluble Mo concentration prevailed in its total content during forced aeration (Figure S4).

170 Finally, As displayed a slightly different behavior. Although its soluble concentration is nearly 171 constant during the first 22 days of passive aeration, a marked increase was observed from day 172 29. This increase is followed by a decrease of its particulate concentration. Unlike other elements, 173 forced aeration had no significant impact on As soluble concentration.

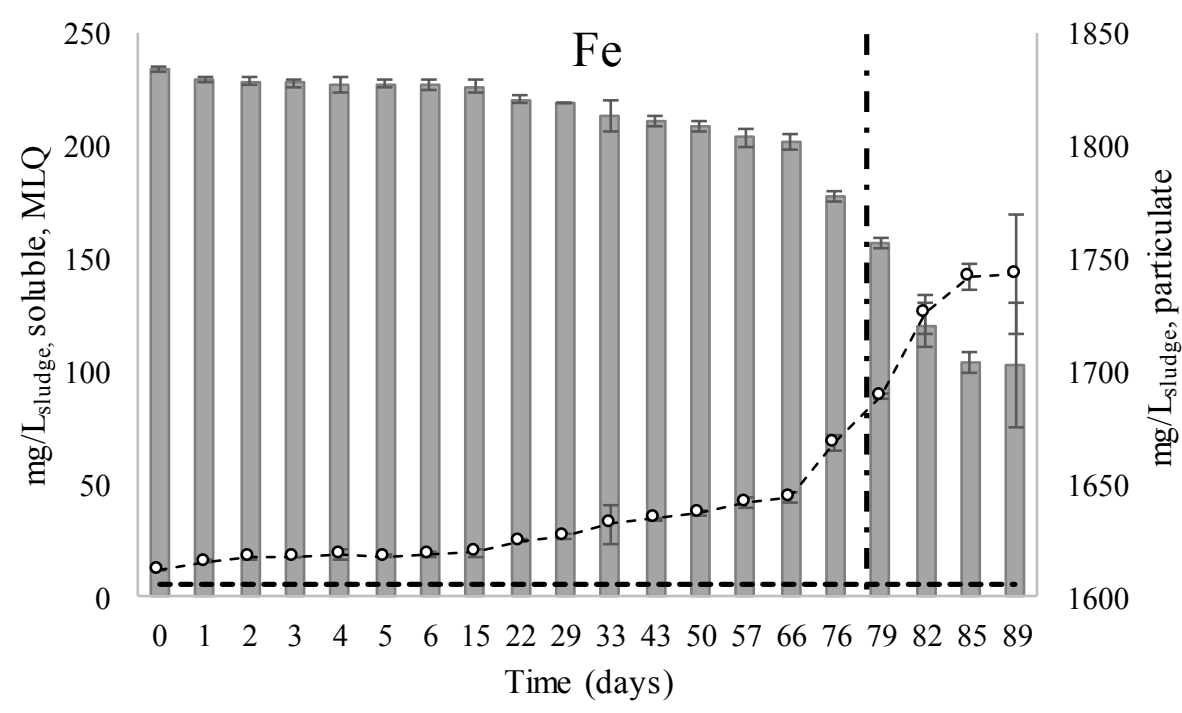



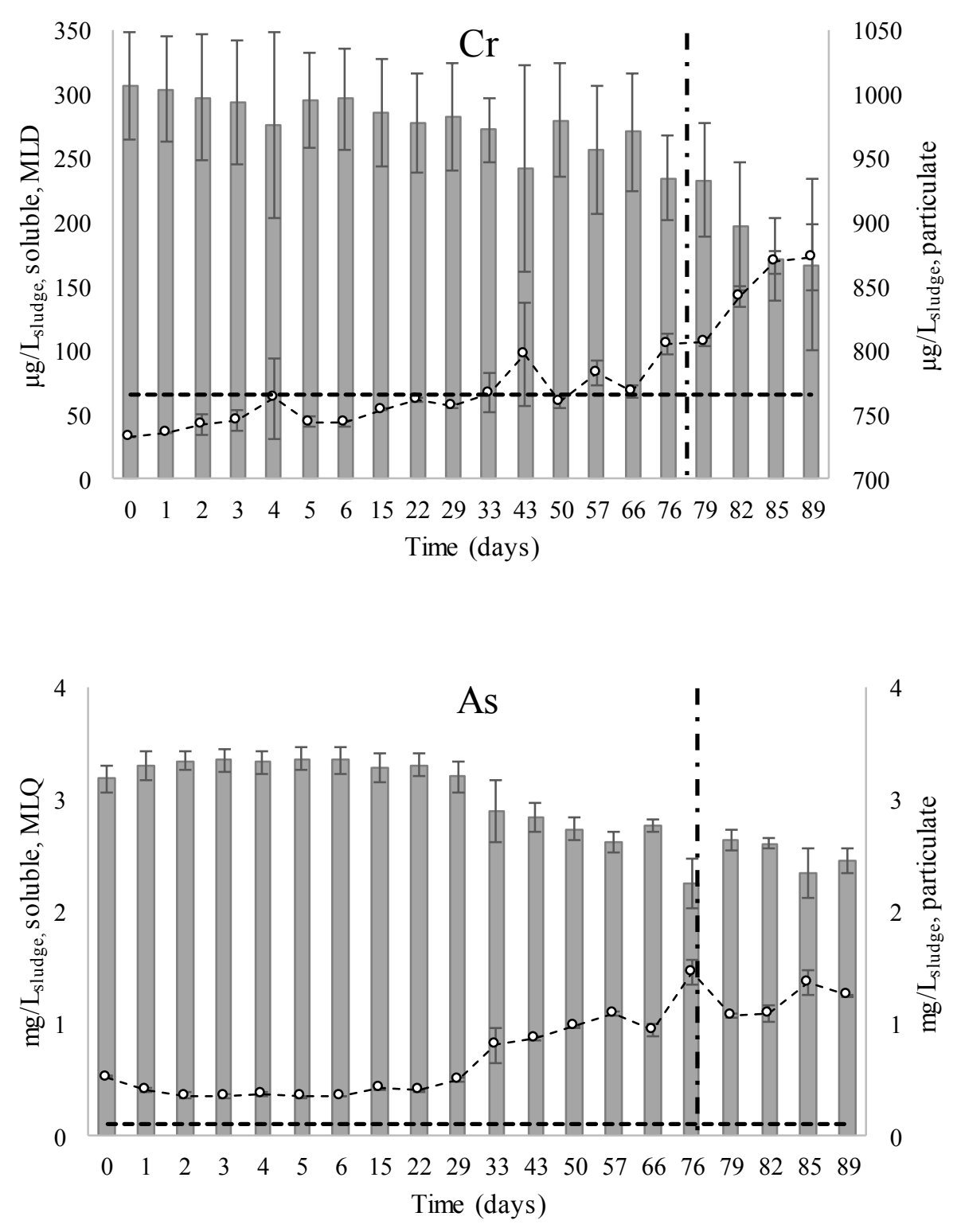

Figure 2. Examples of soluble (dashed line with circles) and particulate (bars) elements' concentration over time. The bold horizontal dashed line is the method limit of detection (MLD) or quantification (MLQ) for soluble elements whereas the vertical dashed line indicates the beginning of forced aeration.

Overall, aeration induces a release in solution of all quantified elements (i.e. $\mathrm{Al}, \mathrm{As}, \mathrm{Co}, \mathrm{Cr}, \mathrm{Cu}$, $181 \mathrm{Fe}, \mathrm{Mn}, \mathrm{Mo}$ and $\mathrm{Pb}$ ). This release was likely caused by direct oxidation of sulfur precipitates in 182 presence of oxygen from the air (Fermoso et al., 2015). However, oxidation performed by 183 indigenous microorganisms such as sulfur oxidizing bacteria (i.e. Acidithiobacillus species) (Jain 184 and Tyagi, 1992) is not excluded, though this hypothesis needs further investigations. In both 
cases, sulfide oxidation leads to metal sulfide precipitates dissolution (e.g. FeS, $\mathrm{CoS}, \mathrm{Cu}_{2} \mathrm{~S}, \mathrm{PbS}$ )

(Maharaj et al., 2018; Möller and Müller, 2012) as well as the release of sulfate. Indeed, a

significant increase of sulfate concentration was measured after the $57^{\text {th }}$ days of passive aeration

188 and during forced aeration (Figure S5). These results are in agreement with the soluble sulfate in

189 sludge suspension found by Carbonell-Barrachina et al. (1999) under oxidizing conditions.

190 Regarding particulate As, it can be hypothesized that it is initially co-precipitated with Fe sulfides

191 (Savage et al., 2000) and consequently released in solution after their dissolution upon oxidation.

192 This is consistent with the slight increase of soluble Fe observed from the $29^{\text {th }}$ day of passive 193 aeration.

\section{3.3. DGT-labile elements concentration}

195 Labile concentrations of $\mathrm{Cd}, \mathrm{Cr}(\mathrm{III}), \mathrm{Cu}$ and $\mathrm{Pb}$ were lower than $0.02,0.2,2,0.6 \mu \mathrm{g} / \mathrm{L}$,

196 respectively, during the whole experiment. The labile concentrations of Mo, Sb and W were close 197 or below the MLD DGT during most of the passive aeration experiment (Figure S5). Labile 198 concentrations of the other elements are given in Figure S5 and typical examples are displayed in 199 Figure 3. Labile Al, As, Co, Fe and Mn rapidly decreased during the first 3-5 days of passive 200 aeration and later their concentration remained rather constant until the $57^{\text {th }}$ day of aeration at 201 least. Conversely, no initial decrease was observed for Ni and Se.

202 Under forced aeration, several elements (i.e. Al, Mo, Ni, Sb, Se and W) displayed a rapid 203 increase of their DGT-labile concentrations followed by a decrease, except for Mo and W. As and 204 Co slightly decreased immediately after forced aeration and their concentration increased again at 205 the $85^{\text {th }}$ day. After 57 days of passive aeration Fe and Mn behavior differs from the other elements since their labile concentrations continued to decrease, even under forced aeration. 
The decrease of labile $\mathrm{Al}$ at the beginning of passive aeration may be explained by the presence of negatively charged hydroxide complexes $\left(e . g . \mathrm{Al}(\mathrm{OH})_{4}{ }^{-}\right)$at $\mathrm{pH} 7.8 \pm 0.3$ that are not efficiently sampled by Chelex-DGT (Panther et al., 2012). The increase of labile Al, As, Co, Ni after 57 210 days of aeration could be a direct consequence of their release form sulfide species as discussed 211 in 3.2. In contrast, the decrease of Fe and Mn labile concentration is not associated with the 212 increase of their soluble fraction, especially at the end of the forced aeration, meaning that part of 213 these soluble elements are DGT-inert (e.g. colloids such as Fe(II)-phosphate or strongly 214 complexed with organic functional groups such as thiol groups (Shakeri Yekta et al., 2014)). 215 Therefore, it can be concluded that oxidation converts a part of labile species of Fe and Mn into 216 soluble non-labile species. Similarly, Øygard et al. (2007) showed a strong decrease of labile Fe 217 (determined with cation exchange SPE cartridge) during the exposition of leachate to oxygen, 218 while particulate and colloidal Fe (e.g. iron oxides) increased.

219 Conversely, the delay observed for the increase of labile As and Co concentration during forced 220 aeration let suppose slow mechanisms of conversion into labile form. Moreover, adsorption onto $221 \mathrm{Fe} / \mathrm{Mn}$ colloids could have occurred.
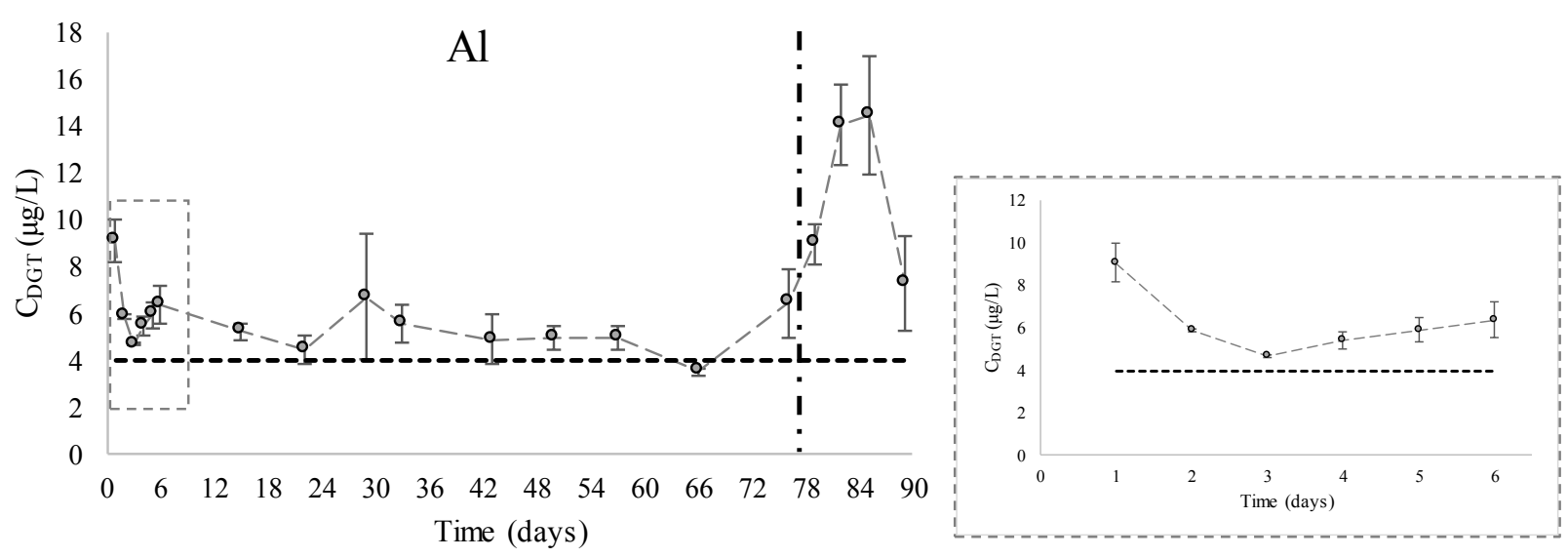

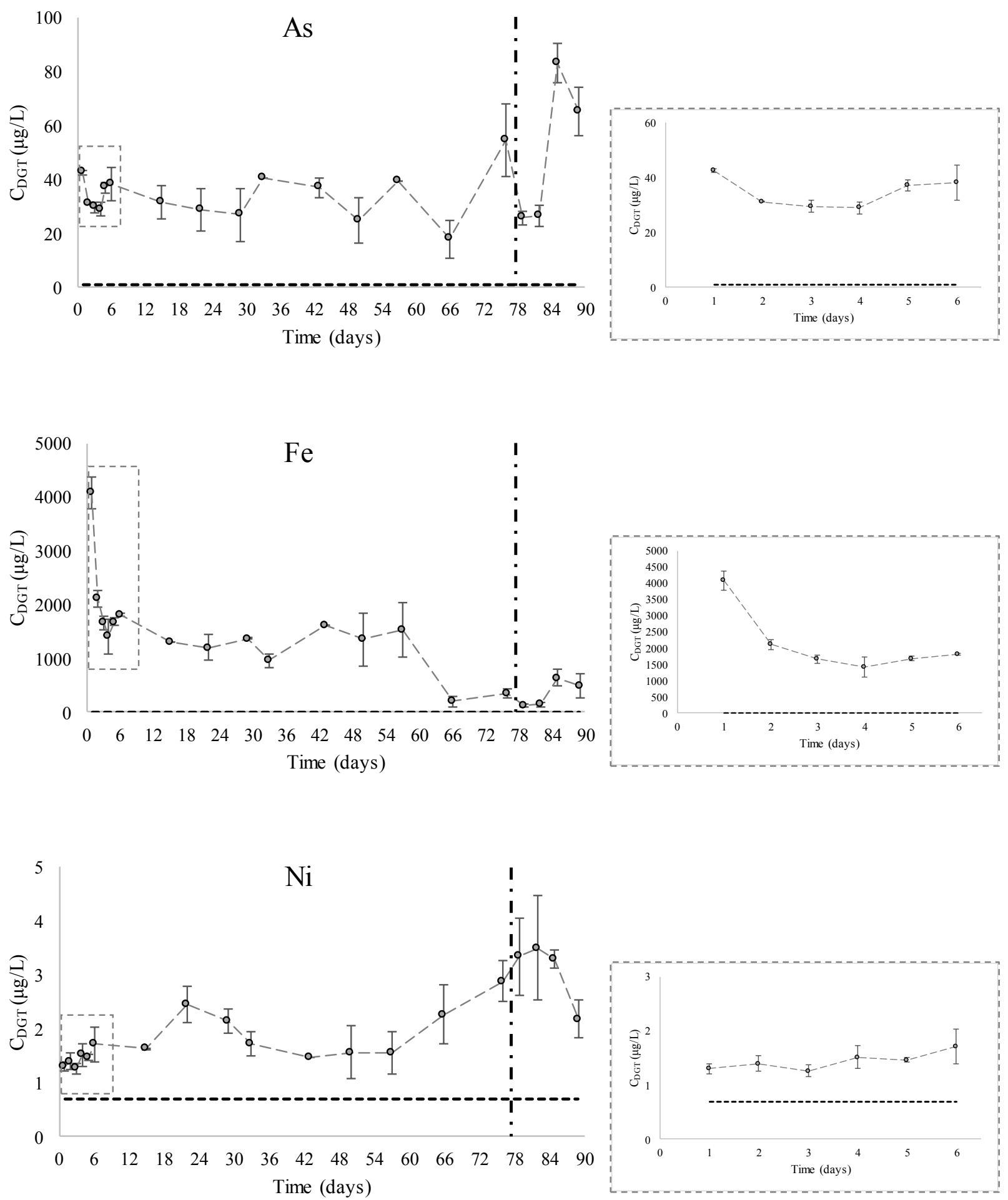

Figure 3. Examples of labile elements' concentration over time. The bold horizontal dashed line is the MLQ DGT $_{\text {Whereas the }}$ vertical dashed line indicates the beginning of forced aeration. The inset is an enlargement of the first 6 days of the experiment. 


\subsection{Environmental impact of digestate aeration}

In this study, performed at laboratory-scale in controlled conditions, it was reported that aeration 230 regime modifies TEs distribution among labile, soluble and particulate fractions. It is assumed

that the observed TEs' fractionation can help to anticipate phenomena related to air exposure occurring on field during digestate management. Indeed, the passive aeration experiment could show the phenomena that can be expected during the storage of digestate in open tanks. Usually, the required storage time of digestate before land spreading may range from 90 days to 10 months depending on the country and digestate spreading season (Plana and Noche, 2016). The variation on TEs' mobility observed during forced aeration is hypothesized to be similar to the one occurring during digestate handling for land application since the contact between air and digestate is significant.

Passive and forced aeration resulted both in a release in solution of $\mathrm{Al}, \mathrm{As}, \mathrm{Co}, \mathrm{Cr}, \mathrm{Cu}, \mathrm{Fe}, \mathrm{Mn}$, $\mathrm{Mo}$ and $\mathrm{Pb}$. Therefore, aeration of digestate could increase mobility of TEs over time. Under passive aeration, dissolution was slow during the first four weeks. Consequently, storage of digestate in an open tank could increase only marginally TEs mobility provided the storage duration is limited. However, dissolution increased significantly after approximately 30 days of passive aeration for most elements. Such increase is likely correlated to the increase of the surface to volume ratio (from $0.39 \mathrm{dm}^{-1}$ to $0.45 \mathrm{dm}^{-1}$ after 30 days of aeration) that controlled the rate of aeration of the digestate during the experiment. Therefore, design of digestate storage tank would be an important parameter to limit the increase of trace element mobility during storage. In this context, digestate storage tank with low surface to volume ratio (i.e. important height) should be favored. Forced aeration resulted in an important dissolution of all the quantified elements, except for As. Therefore, it is assumed that TEs' mobility could be strongly increased during 
4251 digestate handling for land spreading. A "safety factor" which counts for TEs' oxidation during 252 digestate handling should be considered for environmental risk assessment.

253 Alongside particulate/soluble fractions, DGT-labile elements were measured during this study. 254 DGT-labile species (i.e. free + weak complexes) are the most reactive species and would 255 represent the most readily bio-accessible fraction of TEs (Zhang and Davison, 2015). During 256 passive aeration, although soluble elements' concentration increased, no correlated increase of 257 DGT-labile concentrations was found for Al, As, Co, Fe, Mn, and Se. Only DGT-labile Ni 258 showed a small delayed increase ( $\geq 60$ days, within a factor 2 ). Therefore, storage of digestate in 259 an open tank could have no impact on the labile fraction of most of the studied TEs.

260 During forced aeration, except for Fe and Mn, all quantified labile elements rapidly increased. 261 Moreover, the bio-accessibility of labile elements could increase after land application depending 262 on the soils' sorption capacity (Dragicevic et al., 2018b; Kabata-Pendias, 2004) and plants uptake 263 mechanisms (Lehto et al., 2006; Tack, 2010). Such hypothesis should be further studied for risk 264 assessment. It was also observed that labile $\mathrm{Al}, \mathrm{As}, \mathrm{Co}, \mathrm{Ni}, \mathrm{Sb}$ and $\mathrm{Se}$ decreased after one week 265 of forced aeration, therefore, it is not excluded that their bio-accessibility could remain unaltered 266 during digestate land application. 


\section{Conclusions}

268 In this work, the influence of aeration of sewage sludge digestate on the fractionation of fourteen

270 scale tank. Aeration promoted dissolution of all the quantified elements (i.e. $\mathrm{Al}, \mathrm{As}, \mathrm{Co}, \mathrm{Cr}, \mathrm{Cu}$,

$271 \mathrm{Fe}, \mathrm{Mn}, \mathrm{Mo}$ and $\mathrm{Pb}$ ), which was certainly due to oxidation of metal sulfide precipitates.

272 Therefore, it was assumed that the observed increase of TEs mobility due to aeration may likely

273 occur during storage in open tank or digestate handling before land application. However, this

274 dissolution did not promote an increase of DGT-labile concentrations during passive aeration.

275 Conversely, forced aeration promoted an increase of the labile Al, As, Co, Mo, Ni, Sb, Se and W.

276 Therefore, it can be assumed that passive aeration of digestate like in open storage tank would not 277 increase TEs bio-accessibility unless significant aeration such as during digestate handling for 278 land spreading takes place. 


\section{Conflict of interest}

280 The authors declare no conflict of interest.

281 Acknowledgements

14

15

16 


\section{References}

289 Arai, Y., 2010. Arsenic and Antimony, in: Trace Elements in Soils. Wiley-Blackwell, pp. 381290 407. https://doi.org/10.1002/9781444319477.ch16

291 Boulamanti, A.K., Donida Maglio, S., Giuntoli, J., Agostini, A., 2013. Influence of different 292 practices on biogas sustainability. Biomass and Bioenergy 53, 149-161.

$293 \quad$ https://doi.org/10.1016/j.biombioe.2013.02.020

294 Cao, W., Wang, M., Liu, M., Zhang, Z., Sun, Z., Miao, Y., Sun, C., Hu, C., 2018. The chemical and dynamic distribution characteristics of iron, cobalt and nickel in three different anaerobic digestates: Effect of $\mathrm{pH}$ and trace elements dosage. Bioresource Technology 269, 363-374. https://doi.org/10.1016/j.biortech.2018.08.094

Carbonell-Barrachina, A.A., Jugsujinda, A., Burlo, F., Delaune, R.D., Patrick Jr, W.H.., 1999. Arsenic chemistry in municipal sewage sludge as affected by redox potential and $\mathrm{pH}$. Water Res. 34, 216-224.

Charter, R.A., Tabatabai, M.A., Schafer, J.W., 1995. Arsenic, molybdenum, selenium, and tungsten contents of distinct fertilizers and phosphate rocks1. Commun. Soil Sci. Plant Anal.

\section{$303 \quad 26,3051-3062$. https://doi.org/10.1080/00103629509369508}

304 Devillers, D., Buzier, R., Simon, S., Charriau, A., Guibaud, G., 2016. Simultaneous measurement of $\mathrm{Cr}(\mathrm{III})$ and $\mathrm{Cr}(\mathrm{VI})$ in freshwaters with a single Diffusive Gradients in Thin Films device. Talanta 154, 533-538. https://doi.org/10.1016/j.talanta.2016.04.009

307 Dragicevic, I., Eich-Greatorex, S., Sogn, T.A., Horn, S.J., Krogstad, T., 2018a. Use of high metal-containing biogas digestates in cereal production - Mobility of chromium and aluminium. J. Environ. Manage. 217, 12-22. https://doi.org/10.1016/j.jenvman.2018.03.090 
Dragicevic, I., Sogn, T.A., Eich-Greatorex, S., 2018b. Recycling of Biogas Digestates in Crop

Production — Soil and Plant Trace Metal Content and Variability. Front. Sustain. Food Syst. 2, 1-14. https://doi.org/10.3389/fsufs.2018.00045

European Commission, 2016. Sewage Sludge [WWW Document]. URL http://ec.europa.eu/environment/waste/sludge/index.htm (accessed 10.2.18).

315 Fermoso, F.G., van Hullebusch, E.D., Guibaud, G., Collins, G., Svensson, B.H., CarliellMarquet, C., Vink, J.P.M., Esposito, G., Frunzo, L., 2015. Fate of Trace Metals in Anaerobic Digestion, in: Guebitz, G.M., Bauer, A., Bochmann, G., Gronauer, A., Weiss, S. (Eds.), Biogas Science and Technology. Springer International Publishing, Switzerland, pp. 171-195. https://doi.org/10.1007/978-3-319-21993-6_7

320 Fu, M.H., Tabatabai, M.A., 1988. Tungsten Content of Soils, Plants, and Sewage Sludges in 321 Iowa. J. Environ. Qual. 17, 146-148. https://doi.org/10.2134/jeq1988.00472425001700010024x

Hamnér, K., Kirchmann, H., 2015. Trace element concentrations in cereal grain of long-term field trials with organic fertilizer in Sweden. Nutr. Cycl. Agroecosystems 103, 347-358. https://doi.org/10.1007/s10705-015-9749-7

Healy, M.G., Fenton, O., Forrestal, P.J., Danaher, M., Brennan, R.B., Morrison, L., 2016. Metal concentrations in lime stabilised, thermally dried and anaerobically digested sewage sludges. Waste Manag. 48, 404-408. https://doi.org/10.1016/j.wasman.2015.11.028

Hooda, P.S., 2010. Assessing Bioavailability of Soil Trace Elements, in: Trace Elements in Soils. pp. 227-265. https://doi.org/10.1002/9781444319477.ch11

331 Jain, D.K., Tyagi, R.D., 1992. Leaching of heavy metals from anaerobic sewage sludge by sulfur- 
oxidizing bacteria. Enzyme Microb. Technol. 14, 376-383. https://doi.org/10.1016/01410229(92)90006-A

Kabata-Pendias, A., 2004. Soil-plant transfer of trace elements - An environmental issue. Geoderma 122, 143-149. https://doi.org/10.1016/j.geoderma.2004.01.004

Kupper, T., Bürge, D., Bachmann, H.J., Güsewell, S., Mayer, J., 2014. Heavy metals in sourceseparated compost and digestates. Waste Manag. 34, 867-874. https://doi.org/10.1016/j.wasman.2014.02.007

Laera, A., Buzier, R., Guibaud, G., Esposito, G., van Hullebusch, E.D., 2019. Assessment of the DGT technique in digestate to fraction twelve trace elements. Talanta 192, 204-211. https://doi.org/10.1016/j.talanta.2018.09.033

342 Lehto, N.J., Davison, W., Zhang, H., Tych, W., 2006. Analysis of micro-nutrient behaviour in the 343 rhizosphere using a DGT parameterised dynamic plant uptake model. Plant Soil 282, $227-$ 344 238. https://doi.org/10.1007/s11104-005-5848-6

345 Liebetrau, J., Clemens, J., Cuhls, C., Hafermann, C., Friehe, J., Weiland, P., Daniel-Gromke, J., 346 2010. Methane emissions from biogas-producing facilities within the agricultural sector.

347 Eng. Life Sci. 10, 595-599. https://doi.org/10.1002/elsc.201000070

348 Maharaj, B.C., Mattei, M.R., Frunzo, L., van Hullebusch, E.D., Esposito, G., 2018. ADM1 based 349 mathematical model of trace element precipitation/dissolution in anaerobic digestion 350 processes. Bioresour. Technol. 267, 666-676. https://doi.org/10.1016/j.biortech.2018.06.099

351 McBride, M.B., 2003. Toxic metals in sewage sludge-amended soils: Has promotion of 352 beneficial use discounted the risks? Adv. Environ. Res. 8, 5-19. $353 \quad$ https://doi.org/10.1016/S1093-0191(02)00141-7 
Möller, K., Müller, T., 2012. Effects of anaerobic digestion on digestate nutrient availability and

Ortner, M., Rachbauer, L., Somitsch, W., Fuchs, W., 2014. Can bioavailability of trace nutrients be measured in anaerobic digestion? Appl. Energy 126, 190-198. https://doi.org/10.1016/j.apenergy.2014.03.070

Øygard, J.K., Gjengedal, E., Røyset, O., 2007. Size charge fractionation of metals in municipal solid waste landfill leachate. Water Res. 41, 47-54. https://doi.org/10.1016/j.watres.2006.09.027

Panther, J.G., Bennett, W.W., Teasdale, P.R., Welsh, D.T., Zhao, H., 2012. DGT measurement of dissolved aluminum species in waters: Comparing chelex-100 and titanium dioxide-based adsorbents. Environ. Sci. Technol. 46, 2267-2275. https://doi.org/10.1021/es203674n

Plana, P.V., Noche, B., 2016. A review of the current digestate distribution models: storage and transport, in: $8^{\text {Th }}$ International Conference on Waste Management and The Environment. pp. 345-357. https://doi.org/10.2495/WM160311

Repinc, S.K., Šket, R., Zavec, D., Mikuš, K.V., Fermoso, F.G., Stres, B., 2018. Full-scale agricultural biogas plant metal content and process parameters in relation to bacterial and archaeal microbial communities over 2.5 year span. J. Environ. Manage. 213, 566-574. https://doi.org/10.1016/j.jenvman.2018.02.058

372 Riva, C., Orzi, V., Carozzi, M., Acutis, M., Boccasile, G., Lonati, S., Tambone, F., D’Imporzano, 373 G., Adani, F., 2016. Short-term experiments in using digestate products as substitutes for 374 mineral $(\mathrm{N})$ fertilizer: Agronomic performance, odours, and ammonia emission impacts. Sci. 375 Total Environ. 547, 206-214. https://doi.org/10.1016/j.scitotenv.2015.12.156 
Savage, K.S., Tingle, T.N., O’Day, P.A., Waychunas, G.A., Bird, D.K., 2000. Arsenic speciation in pyrite and secondary weathering phases, Mother Lode Gold District, Tuolumne County, California. Appl. Geochemistry 15, 1219-1244. https://doi.org/10.1016/S08832927(99)00115-8

Scarlat, N., Dallemand, J.F., Fahl, F., 2018. Biogas: Developments and perspectives in Europe. Renew. Energy 129, 457-472. https://doi.org/10.1016/j.renene.2018.03.006

Shakeri Yekta, S., Svensson, B.H., Björn, A., Skyllberg, U., Yekta, S.S., Svensson, B.H., Björn, A., Skyllberg, U., 2014. Thermodynamic modeling of iron and trace metal solubility and speciation under sulfidic and ferruginous conditions in full scale continuous stirred tank biogas reactors. Appl. Geochemistry 47, 61-73. https://doi.org/10.1016/j.apgeochem.2014.05.001

Tack, F.M.G., 2010. Trace elements: General soil chemistry, principles and processes, in: Hooda, P. (Ed.), Trace Elements in Soils. Wiley-Blackwell, pp. 9-37. https://doi.org/10.1002/9781444319477.ch2

Tampio, E., Salo, T., Rintala, J., 2016. Agronomic characteristics of five different urban waste digestates. J. Environ. Manage. 169, 293-302. https://doi.org/10.1016/j.jenvman.2016.01.001

van Hullebusch, E.D., Guibaud, G., Simon, S., Lenz, M., Yekta, S.S., Fermoso, F.G., Jain, R., Duester, L., Roussel, J., Guillon, E., Skyllberg, U., Almeida, C.M.R., Pechaud, Y., Garuti, M., Frunzo, L., Esposito, G., Carliell-Marquet, C., Ortner, M., Collins, G., 2016. Methodological approaches for fractionation and speciation to estimate trace element bioavailability in engineered anaerobic digestion ecosystems: An overview. Crit. Rev. 
Vrana, B., Allan, I.J., Greenwood, R., Mills, G.A., Dominiak, E., Svensson, K., Knutsson, J., Morrison, G., 2005. Passive sampling techniques for monitoring pollutants in water. TrAC Trends Anal. Chem. https://doi.org/10.1016/j.trac.2005.06.006

Zhang, H., Davison, W., 2015. Use of diffusive gradients in thin-films for studies of chemical speciation and bioavailability. Environ. Chem. 12, 85-101. https://doi.org/10.1071/EN14105

Zhang, H., Davison, W., 1999. Diffusional characteristics of hydrogels used in DGT and DET techniques. Anal. Chim. Acta 398, 329-340. https://doi.org/10.1016/S0003-2670(99)004584

Zhang, H., Davison, W., 1995. Performance Characteristics of Diffusion Gradients in Thin Films 408 for the in Situ Measurement of Trace Metals in Aqueous Solution. Anal. Chem. 67, 3391$409 \quad 3400$. https://doi.org/10.1021/ac00115a005

410 Zhang, H., Davison, W., Knight, B., Mcgrath, S., 1998. In situ measurements of solution 411 concentrations and fluxes of trace metals in sells using DGT. Environ. Sci. Technol. 32, $412 \quad 704-710$. https://doi.org/10.1021/es9704388 